\title{
Clinical Characteristics and Outcome After Induction of Chemotherapy in Pediatric Acute Lymphoblastic Leukemia: A Descriptive and Correlational Study From the West Bank of Palestine
}

Ramzi Shawahna ( $\sim$ Ramzi_shawahna@hotmail.com)

An-Najah National University

Research article

Keywords: Acute lymphoblastic leukemia, induction chemotherapy, treatment, translocation, Palestine

Posted Date: October 30th, 2020

DOl: https://doi.org/10.21203/rs.3.rs-98522/v1

License: (c) (i) This work is licensed under a Creative Commons Attribution 4.0 International License. Read Full License 


\section{Abstract}

Background

Pediatric acute lymphoblastic leukemia (ALL) is the most prevalent type of cancer among children. This study was conducted to describe and correlate the clinical characteristics and outcomes of treatment of patients with pediatric ALL in the main referral hospital in Palestine.

Methods

In this single-center, retrospective, observational study, paper-based and electronic medical records of patients with pediatric ALL who received induction chemotherapy were reviewed. The sociodemographic variables, details of patient history, findings of physical examinations, daily progress notes, bone marrow biopsies, flow cytometry, and cytogenetics of patients were collected.

Results

Complete data of 69 patients were included in this analysis. The majority (79.7\%) of the patients had B-ALL phenotype, 22 (31.9\%) had abdominal pain, 37 (53.6\%) had fever, 30 (43.5\%) complained of bone pain, 50 (72.5\%) had pallor, 9 (13.0\%) had anorexia, 34 (49.3\%) had hepatomegaly, 34 (49.3\%) had splenomegaly, and $15(21.7 \%)$ complained of bleeding symptoms. After induction chemotherapy, remission was experienced by the vast majority of the patients and $5(7.2 \%)$ experienced relapse after receiving chemotherapy. The vast majority of the patients (96\%) had CNS status $1,1.4 \%$ had CNS status 2 , and $2.9 \%$ had CNS status 3. Cytogenetics for patients with B-ALL phenotype indicated that $10(18.2 \%)$ patients had $t(12,21)$ translocation, $5(9.1 \%)$ had hyperdiploidy, $4(7.3 \%)$ had $t(1,19)$ translocation, and $2(3.6 \%)$ had $t(9,22)$ translocation. The initial white blood cells $(p$ value $<0.001)$, absolute neutrophils $(p$ value $=0.011$ ), and hemoglobin ( $p$ value $<0.001$ ) were significantly lower for patients with B-cell ALL. Platelet counts were significantly lower $(p$ value $=0.012)$ in patients with splenomegaly and those with bleeding symptoms ( $p$ value $=0.008)$. Presence of pollar was positively associated $(p$ value $=0.035)$ with $T$-cell ALL. Presence of hepatomegaly was positively associated ( $p$ value $<0.001$ ) with splenomegaly.

Conclusion

Overall, this study provides insights into the clinical characteristics and outcomes of induction chemotherapy in Palestinian patients with pediatric ALL. The characteristics of ALL among Palestinians were comparable to their peers in the region. The outcomes of induction chemotherapy were also comparable to other published data for ALL patients.

\section{Background}

Cancer is the second most common cause of mortality among Palestinians in the West Bank and Gaza Strip [1]. In general, leukemias are the most common types of cancers among Palestinian children with an estimated incidence rate of 2.6 per 100,000 children [1, 2]. Acute lymphoblastic leukemia (ALL) is the most diagnosed tumor in pediatric populations and the most frequent cause of death from cancer before the age of 20 [3]. According to some estimates, more than $75 \%$ of pediatric leukemias are ALL. One annual basis, about 6,000 ALL cases are diagnosed in the US, of those, about $50 \%$ are children and teenagers [4, 5]. In the US, ALL is more common in Caucasians and Hispanics compared to African Americans [6]. Reports on the prevalence of pediatric ALL in the Middle East, especially, among the Palestinian population are scarce [2]. The Middle East Childhood Cancer Alliance (MECCA) collected clinical and demographic data on children with ALL from 16 countries in the Middle East [7]. It is noteworthy mentioning that Palestinians were not included in the MECCA's study [7].

ALL is a result of clonal proliferation of early lymphoid precursors (lymphoid stem or progenitor cells) with arrested maturation [8, 9]. ALL occurs more frequently in B-lineage (B-cell precursor immunophenotype or B-ALL) compared to T-lineage (T-cell precursor immunophenotype or T-ALL) [9]. Of patients with pediatric ALL, approximately $80 \%$ have B-ALL $[7,10,11]$. On the other hand, patients with T-ALL comprise about $10 \%-15 \%$ the patients. Historically, patients with pediatric T-ALL showed lower cure rates [12].

Structural mutations of the chromosomes including aneuploidy and translocations are characteristic features in ALL. The World Health Organization (WHO) classifies B-ALL on the basis of molecular and cytogenetic characteristics [13]. Aneuploidy include high-hyperdiploid (chromosomes $\geq 51$ ) and hypodiploid (chromosomes $\leq 44$ ) and translocations include $\mathrm{t}(12 ; 21)$ / ETV6-RUNX1, $\mathrm{t}(1 ; 19) / T C F 3-P B X 1, \mathrm{t}(9 ; 22) / B C R-A B L 1$, and KMT2A rearrangement [11, 14, 15]. Currently, 9 subtypes have been identified and classified by specific translocations on chromosomes, rearrangements, and ploidy status [9, 11, 13]. Historically, subtypes of ALL are shown to be associated with variable risk of disease progression and response to treatment options [16-18].

Clinical presentation of ALL may include fever, signs indicative of anemia (for example: pallor, tachycardia, fatigue, and headache), increased risk of infection, and bleeding $[19,20]$. Currently, protocols of treatment stratify patients by risk to receive chemotherapy of multiple agents that can lead to cure rates of up to $90 \%$ in countries with high income [17]. It is noteworthy mentioning that despite the initial response to therapy, 10-15\% of the patients experience relapse. This relapse is considered one of the leading causes of mortality in childhood cancers [21,22]. Therefore, early diagnosis and optimizing prognosis are of crucial importance.

Diagnosis of pediatric ALL is often based on physical examination, complete blood count, and blood smears. In the majority of cases, blast cells are seen on blood smears. Biopsies of bone marrow are also used to provide a conclusive diagnosis [23]. Lumbar punctures could also be used to determine involvement of the central nervous system [24]. Additionally, complete blood count, clinical findings, and cytogenetics are frequently used in deciding on the risk-stratified and multi-agent chemotherapy $[15,17,20,25]$.

Description of epidemiological and clinical characteristics of patients with ALL in different nations has received considerable attention [26]. In Palestine, cancer care is highly fragmented and a high percentage of patients receive treatment outside the country [1, 27]. Currently, referral hospitals in which patients 
with pediatric ALL receive induction chemotherapy in Palestine are limited [1, 27]. Since its inception, An-Najah National Hospital has emerged as the main referral hospital for pediatric ALL in Palestine.

Ayesh et al determined the frequency of thiopurine methyltransferase polymorphisms and whether polymorphisms were associated with side effects of 6mercaptopurine using 56 DNA samples from patients with pediatric ALL in Gaza Strip [28]. Abuhelwa et al reported the characteristics of patients with de novo acute myeloid leukemia in Palestine [29]. However, little is known on the clinical characteristics and outcomes of induction chemotherapy among patients with pediatric ALL in Palestine. Therefore, this study was conducted to describe the clinical characteristics and outcomes of induction chemotherapy among patients with pediatric ALL in the main referral hospital in Palestine. The study also aimed to assess associations between sociodemographic and clinical characteristics of the patients included in the study.

\section{Methods \\ Study site}

The study was conducted at An-Najah National Hospital, Nablus. Since its inception in 2014, An-Najah National Hospital has become the main referral care center for patients with pediatric ALL and adult leukemias in Palestine. The hospital has an active oncology department in which about 800 patients from the West Bank of Palestine and Gaza Strip receive treatment for different cancers on annual basis.

\section{Study participants}

Patients with pediatric ALL were included in this study. The inclusion criteria were: a) patients who were 16 years old and younger, b) admitted to the referral hospital with a diagnosis of pediatric ALL, and c) received induction chemotherapy at the study site. We did not restrict inclusion based on gender or admission dates. Therefore, all patients of both genders who were admitted to the study site from its inception (January 2014 ) to January 2018 were included in the present study. Patients with incomplete medical records and those who received their induction chemotherapy outside the referral hospital were excluded from the study.

\section{Study design, tools, and collection of data}

This present study was a single-center, retrospective, observational study. The study used a descriptive-correlational approach. In this study, paper-based and electronic medical records of patients with pediatric ALL were reviewed by field researchers. A data collection form that was created for this study using Excel Spreadsheets (Microsoft Excel, Microsoft Inc, US) was used to extract the pertinent data (Additional file 1). The data collected for this study were informed by previous studies $[7,29,30]$. The data collected for the purpose of this study included: sociodemographic variables like age and gender, detailed patient history, detailed findings of the physical examination, and daily progress notes of each patient. Hematological reports were reviewed and hemoglobin levels, platelet counts, initial white blood cells (WBCs) counts, and absolute neutrophils counts were collected. Clinical characteristics like presence of abdominal pain, fever, bone pain, central nervous system (CNS) status, fatigue, anorexia, hepatomegaly, splenomegaly, and bleeding symptoms were also collected. The data collection form also collected information relevant to bone marrow biopsies, flow cytometry, and cytogenetics (Additional file 1). Data were collected from the time the patient was admitted until outcomes of induction became available. The outcomes of the induction were assessed based on the bone narrow biopsies performed on days 19-21 after initiation of induction chemotherapy. In this study, the outcomes were classified as follows: a) remission ((< 5\% blasts on bone marrow), b) non-remission ( $\geq 5 \%$ blasts on bone marrow), c) relapse ( $\geq 20 \%$ blasts in bone marrow, any blasts in CNS or both), or d) death of the patient during the first admission for the induction chemotherapy.

\section{Ethical approval}

The protocol and ethics of this study were approved by the Institutional Review Board (IRB) of An-Najah National University under the archived number (IRB20-2017). Data and information leading to the identity of the patient were not collected into the data collection form. The data were coded during the data analysis.

\section{Statistical analysis}

Data were entered into IBM SPSS for Windows v.21.0 (IBM Inc. Armonk, New York). Kolmogorov-Smirnov test was used to assess whether the data were normally distributed or not. Because the data were not normally distributed, the data were expressed using medians and their corresponding interquartile range (IQR). Categorical data were compared using Mann-Whitney Utest. Correlation was investigated using Spearman's rank correlations. Statistical significance was considered when the $p$ value was $<0.05$.

\section{Results}

All medical records of patients who received induction chemotherapy at An-Najah National Hospital were reviewed. Complete records and laboratory reports were identified for a total of 69 patients. Patients with complete records and laboratory reports were included in the final analysis. 


\section{Sociodemographic and clinical characteristics of the study patients}

The median age of the patients at presentation was 6.0 with an IQR of 3.5 years. Of all patients, 26 (37.7\%) were younger than 10 years of age, and 43 (62.3\%) were at least 10 years of age or older. Of the patients included, $42(60.9 \%)$ were male and $27(39.1 \%)$ were female in gender. With regard to the signs and symptoms at presentation, 22 (31.9\%) patients had abdominal pain, 37 (53.6\%) had fever, 30 (43.5\%) complained of bone pain, 50 (72.5\%) had pallor, 9 (13.0\%) had anorexia, 34 (49.3\%) had hepatomegaly, 34 (49.3\%) had splenomegaly, and 15 (21.7\%) complained of bleeding symptoms. After induction of chemotherapy, 5 (7.2\%) patients experienced relapse after receiving treatments. The vast majority of the patients ( $96 \%$ ) had CNS status $1,1.4 \%$ had CNS status 2 , and $2.9 \%$ had CNS status 3 . The majority of the patients had B-ALL (79.7\%) and $20.3 \%$ had T-ALL. Details of the sociodemographic and clinical characteristics of the patients are shown in Table 1.

Cytogenetic studies for the B-ALL phenotype showed that 10 (18.2\%) patients had t(12,21) translocation, 5 (9.1\%) had hyperdiploidy, 4 (7.3\%) had $t(1,19)$ translocation, and $2(3.6 \%)$ had $t(9,22)$ translocation. Of all patients, $19(34.5 \%)$ did not have any of the previously mentioned abnormal cytogenetics (Table 1).

Table 1: Sociodemographic and clinical characteristics of the patients with pediatric ALL included in the study $(n=69)$ 


\begin{tabular}{|c|c|c|}
\hline Characteristic & $\mathbf{n}$ & $\%$ \\
\hline \multicolumn{3}{|l|}{ Age (years) } \\
\hline$<10$ & 26 & 37.7 \\
\hline$\geq 10$ & 43 & 62.3 \\
\hline \multicolumn{3}{|l|}{ Gender } \\
\hline Male & 42 & 60.9 \\
\hline Female & 27 & 39.1 \\
\hline \multicolumn{3}{|c|}{ Presence of abdominal pain } \\
\hline Yes & 22 & 31.9 \\
\hline No & 47 & 68.1 \\
\hline \multicolumn{3}{|c|}{ Presence of fever } \\
\hline Yes & 37 & 53.6 \\
\hline No & 32 & 46.4 \\
\hline \multicolumn{3}{|c|}{ Presence of bone pain } \\
\hline Yes & 30 & 43.5 \\
\hline No & 39 & 56.5 \\
\hline \multicolumn{3}{|l|}{ CNS status $^{1}$} \\
\hline CNS 1 & 66 & 95.7 \\
\hline CNS 2 & 1 & 1.4 \\
\hline CNS 3 & 2 & 2.9 \\
\hline \multicolumn{3}{|c|}{ Presence of pallor } \\
\hline Yes & 50 & 72.5 \\
\hline No & 19 & 27.5 \\
\hline \multicolumn{3}{|c|}{ Presence of anorexia } \\
\hline Yes & 9 & 13.0 \\
\hline No & 60 & 87.0 \\
\hline \multicolumn{3}{|c|}{ Presence of hepatomegaly ${ }^{2}$} \\
\hline Yes & 34 & 49.3 \\
\hline No & 35 & 50.7 \\
\hline \multicolumn{3}{|c|}{ Presence of splenomegaly ${ }^{3}$} \\
\hline Yes & 34 & 49.3 \\
\hline No & 35 & 50.7 \\
\hline \multicolumn{3}{|c|}{ Presence of bleeding 4} \\
\hline Yes & 15 & 21.7 \\
\hline No & 54 & 78.3 \\
\hline \multicolumn{3}{|c|}{ Immunophenotype } \\
\hline B-ALL & 55 & 79.7 \\
\hline T-ALL & 14 & 20.3 \\
\hline \multicolumn{3}{|c|}{ Cytogenetics for B-ALL } \\
\hline$t(12,21)$ & 10 & 18.2 \\
\hline Hyperdiploidy & 5 & 9.1 \\
\hline$t(1,19)$ & 4 & 7.3 \\
\hline$t(9,22)$ & 2 & 3.6 \\
\hline
\end{tabular}

Page 5/12 


\begin{tabular}{|lll|}
\hline Characteristic & $\mathbf{n}$ & $\%$ \\
\hline Nil & 19 & 34.5 \\
\hline Missing & 15 & 27.3 \\
\hline Relapse $^{5}$ & & \\
\hline Yes & 5 & 7.2 \\
\hline No & 64 & 92.8 \\
\hline Remission & \\
Yes & & \\
\hline No & 68 & 98.5 \\
\hline
\end{tabular}

${ }^{1}$ CNS1: WBC in CSF $\otimes 5$ without WBC blasts, CNS2: WBC in CSF $\otimes 5$ with WBC blasts, CNS3: WBC in CSF $\otimes 5$ with WBC blasts; ${ }^{2}$ Hepatomegaly: palpable liver below the costal margin; ${ }^{3}$ Splenomegaly: palpable spleen; ${ }^{4}$ Presence of bleeding symptoms like petechiae, epistaxis, bruising, gum bleeding, blood in stool; ${ }^{5}$ Relapse: Patient was in remission and developing any of the following: 1 . More than $20 \%$ of blasts in bone marrow, or, 2 . CNS status 2 or 3 , or, 3 . Both $1+2$; ${ }^{6}$ Remission: The percentage of blast cells in the bone marrow is less than $5 \%$ at the end of induction of chemotherapy.

\section{Hematological laboratory data at admission}

The median hemoglobin at admission was 9.00 with an IQR of $2.70 \mathrm{~g} / \mathrm{dL}$. The median platelet count was 80,000 with an IQR of 157,000 platelets/mm ${ }^{3}$. For the initial WBCs count, the median was 7,100 with an IQR of 20,600 cells $/ \mathrm{mm}^{3}$. For the absolute neutrophils count, the median was 1,420 with an IQR of 2,030 cells $/ \mathrm{mm}^{3}$. The detailed hematological laboratory data of the study participants are shown in Table 2.

Table 2: Hematological laboratory data at admission $(n=69)$

\begin{tabular}{|c|c|c|c|c|}
\hline Statistic & Hemoglobin (g/dL) & Platelet count (per mm³) & Initial WBCs count (cells/mm³) & Absolute neutrophils count (cells $/ \mathrm{mm}^{3}$ ) \\
\hline Median & 9.00 & 80000 & 7100 & 1420 \\
\hline IQR & 2.70 & 157000 & 20600 & 2030 \\
\hline
\end{tabular}

IQR: interquartile range, WBCs: white blood cells

\section{Association between the different sociodemographic and clinical characteristics of the study patients with their hematologic laboratory findings}

The median hemoglobin in patients who were 5 years of age and older ( 9.1 with an IQR of $2.5 \mathrm{~g} / \mathrm{dL}$ ) was significantly higher ( $\mathrm{p}$ value $=0.007)$ than those who were younger than 5 years $(7.8$ with an IQR of $2.8 \mathrm{~g} / \mathrm{dL}$ ). The median platelet count in patients who did not have splenomegaly (122,000 with an IQR of $169,000)$ was significantly higher ( $p$ value $=0.012)$ than those who had splenomegaly $(49,500$ with an IQR of 145,850$)$. The median platelet count for patients who did not have bleeding symptoms $(103,000$ with an IQR of 171,000) was significantly higher ( $p$ value $=0.008)$ than those who had bleeding symptoms (34,000 with an IQR of 66,050). The median hemoglobin for patients who had T-ALL (11.2 with an IQR 2.8) was significantly higher ( $\mathrm{p}$ value < 0.001$)$ than those who had B-ALL (8.4 with an IQR of 2.5). The median initial WBCs count for patients who had T-ALL $(22,100$ with an IQR 35,550$)$ was significantly higher ( $p$ value $<0.001)$ than those who had B-ALL $(5,000$ with an IQR of 10,950). The median absolute neutrophil count for patients who had T-ALL $(2,670$ with an IQR of 4,595$)$ was significantly higher ( $p$ value $=0.011$ ) than those who had B-ALL $(1,050$ with an IQR 1,730$)$. Other variables were not significantly associated ( $p$ value $>0.05$ ). The details of associated variables are shown in Table 3.

Table 3: Association between sociodemographic and clinical characteristics and hematologic findings of patients with pediatric ALL 


\begin{tabular}{|c|c|c|c|c|c|c|c|c|c|c|c|c|c|c|c|}
\hline \multirow[b]{2}{*}{ Characteristic } & \multirow[b]{2}{*}{$\mathrm{n}$} & \multirow[b]{2}{*}{$\%$} & \multicolumn{4}{|c|}{ Hemoglobin $(\mathrm{g} / \mathrm{dL})$} & \multicolumn{4}{|c|}{ Platelet count } & \multicolumn{4}{|c|}{ Initial WBC count } & \multirow{2}{*}{$\begin{array}{l}A \\
M\end{array}$} \\
\hline & & & Median & IQR & $\begin{array}{l}\text { Mean } \\
\text { rank }\end{array}$ & $\begin{array}{l}P \\
\text { value }\end{array}$ & Median & IQR & $\begin{array}{l}\text { Mean } \\
\text { rank }\end{array}$ & $\begin{array}{l}P \\
\text { value }\end{array}$ & Median & IQR & $\begin{array}{l}\text { Mean } \\
\text { rank }\end{array}$ & $\begin{array}{l}\mathrm{P} \\
\text { value }\end{array}$ & \\
\hline \multicolumn{16}{|l|}{ Age (years) } \\
\hline$<10$ & 26 & 37.7 & 7.8 & 2.8 & 26.6 & \multirow[t]{2}{*}{0.007} & 57000 & 93000 & 30.2 & \multirow[t]{2}{*}{0.119} & 7700 & 26400 & 37.3 & \multirow[t]{2}{*}{0.454} & $1:$ \\
\hline$\geq 10$ & 43 & 62.3 & 9.1 & 2.5 & 40.1 & & 118500 & 167000 & 37.9 & & 4600 & 11028 & 33.6 & & 14 \\
\hline \multicolumn{16}{|l|}{ Gender } \\
\hline Male & 42 & 60.9 & 8.5 & 3.0 & 38.3 & \multirow[t]{2}{*}{0.088} & 87000 & 162500 & 36.1 & \multirow[t]{2}{*}{0.563} & 7100 & 18700 & 38.4 & \multirow[t]{2}{*}{0.077} & 16 \\
\hline Female & 27 & 39.1 & 9.0 & 3.6 & 29.9 & & 67000 & 171000 & 33.3 & & 5000 & 7550 & 29.7 & & 94 \\
\hline \multicolumn{16}{|c|}{$\begin{array}{l}\text { Presence of } \\
\text { abdominal pain }\end{array}$} \\
\hline Yes & 22 & 31.9 & 9.0 & 3.5 & 34.2 & \multirow[t]{2}{*}{0.822} & 88500 & 179000 & 35.6 & \multirow[t]{2}{*}{0.867} & 5100 & 10670 & 36.4 & \multirow[t]{2}{*}{0.690} & $1:$ \\
\hline No & 47 & 68.1 & 8.8 & 3.0 & 35.4 & & 64000 & 167000 & 34.7 & & 7100 & 16700 & 34.3 & & $1 !$ \\
\hline \multicolumn{16}{|c|}{ Presence of fever } \\
\hline Yes & 37 & 53.6 & 9.0 & 2.6 & 37.8 & \multirow[t]{2}{*}{0.217} & 78000 & 155250 & 34.7 & \multirow[t]{2}{*}{0.909} & 4900 & 17178 & 34.8 & 0.942 & $1:$ \\
\hline No & 32 & 46.4 & 8.5 & 2.5 & 31.8 & & 64000 & 180500 & 35.3 & & 7700 & 13950 & 35.2 & & $1 !$ \\
\hline $\begin{array}{l}\text { Presence of bo } \\
\text { pain }\end{array}$ & & & & & & & & & & & & & & & \\
\hline Yes & 30 & 43.5 & 9.1 & 2.9 & 34.8 & 0.928 & 59000 & 123000 & 33.2 & 0.506 & 5300 & 13100 & 33.4 & 0.553 & 16 \\
\hline No & 39 & 56.5 & 8.7 & 2.2 & 35.2 & & 88500 & 185500 & 36.4 & & 5650 & 16725 & 36.3 & & $9^{-}$ \\
\hline Pallor & & & & & & & & & & & & & & & \\
\hline Yes & 50 & 72.5 & 8.5 & 2.8 & 32.6 & 0.111 & 84000 & 157000 & 35.9 & 0.537 & 5300 & 13970 & 34.0 & 0.515 & 14 \\
\hline No & 19 & 27.5 & 9.4 & 3.5 & 41.2 & & 65500 & 211800 & 32.6 & & 7300 & 19750 & 37.6 & & 14 \\
\hline $\begin{array}{l}\text { Presence of } \\
\text { anorexia }\end{array}$ & & & & & & & & & & & & & & & \\
\hline Yes & 9 & 13.0 & 8.3 & 2.6 & 30.3 & 0.449 & 121000 & 168000 & 37.3 & 0.708 & 17700 & 32350 & 40.8 & 0.354 & $1 !$ \\
\hline No & 60 & 87.0 & 9.0 & 2.5 & 35.7 & & 71000 & 158000 & 34.7 & & 5000 & 12643 & 34.1 & & 14 \\
\hline $\begin{array}{l}\text { Presence of } \\
\text { hepatomegaly }\end{array}$ & & & & & & & & & & & & & & & \\
\hline Yes & 34 & 49.3 & 9.0 & 1.6 & 36.1 & 0.644 & 50000 & 144500 & 31.5 & 0.151 & 5000 & 15750 & 36.6 & 0.513 & 1 \\
\hline No & 35 & 50.7 & 8.3 & 3.8 & 33.9 & & 118500 & 173000 & 38.4 & & 6350 & 14350 & 33.4 & & 14 \\
\hline $\begin{array}{l}\text { Presence of } \\
\text { splenomegaly }\end{array}$ & & & & & & & & & & & & & & & \\
\hline Yes & 34 & 49.3 & 9.0 & 1.7 & 37.1 & 0.381 & 49500 & 145850 & 28.8 & 0.012 & 7200 & 24300 & 38.0 & 0.216 & 16 \\
\hline No & 35 & 50.7 & 7.8 & 3.0 & 32.9 & & 122000 & 169000 & 41.0 & & 5200 & 9250 & 32.1 & & 11 \\
\hline $\begin{array}{l}\text { Presence of } \\
\text { bleeding }\end{array}$ & & & & & & & & & & & & & & & \\
\hline Yes & 15 & 21.7 & 8.0 & 4.5 & 30.6 & 0.333 & 34000 & 66050 & 22.9 & 0.008 & 9600 & 12335 & 39.1 & 0.367 & 16 \\
\hline No & 54 & 78.3 & 8.9 & 2.2 & 36.2 & & 103000 & 171000 & 38.4 & & 4900 & 15300 & 33.9 & & $1:$ \\
\hline Immunopheno & & & & & & & & & & & & & & & \\
\hline B-cell ALL & 55 & 79.7 & 8.4 & 2.5 & 30.0 & $<0.001$ & 72000 & 156000 & 34.3 & 0.546 & 5000 & 10950 & 30.6 & $<0.001$ & 11 \\
\hline T-cell ALL & 14 & 20.3 & 11.2 & 2.8 & 54.6 & & 97500 & 264600 & 37.9 & & 22100 & 35550 & 52.3 & & $2 t$ \\
\hline Relapse $^{5}$ & & & & & & & & & & & & & & & \\
\hline Yes & 5 & 7.2 & 7.8000 & 1.35 & 31.8 & 0.711 & 60500 & 166750 & 38.2 & 0.711 & 1290 & 12353 & 24.7 & 0.233 & $2 !$ \\
\hline No & 64 & 92.8 & 9.0000 & 2.80 & 35.3 & & 84000 & 166000 & 34.8 & & 5600 & 14500 & 35.8 & & $1 !$ \\
\hline
\end{tabular}




\section{Correlation between sociodemographic and clinical characteristics of patients with pediatric ALL}

There was a positive correlation ( $p$ value $=0.035$ ) between presence of pallor at presentation and T-ALL immunophenotype. Again, there was a positive correlation ( $p$ value $<0.001$ ) between presence of hepatomegaly and presence of splenomegaly. Other variables were not significantly correlated $(p$ value $>$ 0.05). The detailed correlations are shown in Table 4.

Table 4: Correlation between sociodemographic and clinical characteristics of patients with pediatric ALL

\begin{tabular}{|c|c|c|c|c|c|c|c|c|c|c|}
\hline Characteristic & Correlation & $\begin{array}{l}\text { Presence } \\
\text { of } \\
\text { abdominal } \\
\text { pain }\end{array}$ & $\begin{array}{l}\text { Presence } \\
\text { of fever }\end{array}$ & $\begin{array}{l}\text { Presence } \\
\text { of bone } \\
\text { pain }\end{array}$ & $\begin{array}{l}\text { CNS } \\
\text { status }\end{array}$ & $\begin{array}{l}\text { Presence } \\
\text { of pallor }\end{array}$ & $\begin{array}{l}\text { Presence } \\
\text { of } \\
\text { anorexia }\end{array}$ & $\begin{array}{l}\text { Presence of } \\
\text { hepatomegaly }\end{array}$ & $\begin{array}{l}\text { Presence of } \\
\text { splenomegaly }\end{array}$ & $\begin{array}{l}\text { Presence } \\
\text { of } \\
\text { bleeding }\end{array}$ \\
\hline \multirow[t]{2}{*}{$\begin{array}{l}\text { Presence of } \\
\text { abdominal pain }\end{array}$} & $\begin{array}{l}\text { Spearman's } \\
\text { rho }\end{array}$ & - & 0.01 & -0.04 & -0.01 & 0.14 & -0.08 & 0.20 & 0.20 & 0.17 \\
\hline & $\mathrm{p}$ value & & 0.918 & 0.772 & 0.943 & 0.240 & 0.512 & 0.106 & 0.106 & 0.170 \\
\hline \multirow[t]{2}{*}{ Presence of fever } & $\begin{array}{l}\text { Spearman's } \\
\text { rho }\end{array}$ & 0.01 & - & 0.11 & 0.08 & 0.21 & 0.10 & -0.07 & -0.07 & 0.00 \\
\hline & $\mathrm{p}$ value & 0.918 & & 0.359 & 0.489 & 0.087 & 0.408 & 0.559 & 0.559 & 0.980 \\
\hline \multirow[t]{2}{*}{$\begin{array}{l}\text { Presence of bone } \\
\text { pain }\end{array}$} & $\begin{array}{l}\text { Spearman's } \\
\text { rho }\end{array}$ & -0.04 & 0.11 & - & 0.05 & 0.02 & -0.08 & -0.16 & -0.22 & -0.04 \\
\hline & $\mathrm{p}$ value & 0.772 & 0.359 & & 0.697 & 0.889 & 0.517 & 0.182 & 0.068 & 0.763 \\
\hline \multirow[t]{2}{*}{ CNS status } & $\begin{array}{l}\text { Spearman's } \\
\text { rho }\end{array}$ & -0.01 & 0.08 & 0.05 & - & 0.02 & 0.08 & -0.07 & -0.07 & -0.05 \\
\hline & $\mathrm{p}$ value & 0.943 & 0.489 & 0.697 & & 0.851 & 0.500 & 0.556 & 0.556 & 0.654 \\
\hline \multirow[t]{2}{*}{ Presence of pallor } & $\begin{array}{l}\text { Spearman's } \\
\text { rho }\end{array}$ & 0.14 & 0.21 & 0.02 & 0.02 & - & 0.14 & 0.09 & -0.11 & 0.09 \\
\hline & $\mathrm{p}$ value & 0.240 & 0.087 & 0.889 & 0.851 & & 0.243 & 0.470 & 0.385 & 0.467 \\
\hline \multirow[t]{2}{*}{$\begin{array}{l}\text { Presence of } \\
\text { anorexia }\end{array}$} & $\begin{array}{l}\text { Spearman's } \\
\text { rho }\end{array}$ & -0.08 & 0.10 & -0.08 & 0.08 & 0.14 & - & -0.04 & 0.13 & 0.11 \\
\hline & $\mathrm{p}$ value & 0.512 & 0.408 & 0.517 & 0.500 & 0.243 & & 0.760 & 0.270 & 0.373 \\
\hline \multirow[t]{2}{*}{$\begin{array}{l}\text { Presence of } \\
\text { hepatomegaly }\end{array}$} & $\begin{array}{l}\text { Spearman's } \\
\text { rho }\end{array}$ & 0.20 & -0.07 & -0.16 & -0.07 & 0.09 & -0.04 & - & 0.77 & 0.04 \\
\hline & $p$ value & 0.106 & 0.559 & 0.182 & 0.556 & 0.470 & 0.760 & & 0.000 & 0.727 \\
\hline \multirow[t]{2}{*}{$\begin{array}{l}\text { Presence of } \\
\text { splenomegaly }\end{array}$} & $\begin{array}{l}\text { Spearman's } \\
\text { rho }\end{array}$ & 0.20 & -0.07 & -0.22 & -0.07 & -0.11 & 0.13 & 0.77 & - & 0.11 \\
\hline & $\mathrm{p}$ value & 0.106 & 0.559 & 0.068 & 0.556 & 0.385 & 0.270 & $<0.001$ & & 0.355 \\
\hline \multirow[t]{2}{*}{$\begin{array}{l}\text { Presence of } \\
\text { bleeding }\end{array}$} & $\begin{array}{l}\text { Spearman's } \\
\text { rho }\end{array}$ & 0.17 & 0.00 & -0.04 & -0.05 & 0.09 & 0.11 & 0.04 & 0.11 & - \\
\hline & $p$ value & 0.170 & 0.980 & 0.763 & 0.654 & 0.467 & 0.373 & 0.727 & 0.355 & \\
\hline \multirow[t]{2}{*}{ Immunophenotype } & $\begin{array}{l}\text { Spearman's } \\
\text { rho }\end{array}$ & 0.04 & 0.11 & 0.22 & -0.11 & 0.25 & 0.09 & 0.06 & -0.01 & 0.00 \\
\hline & $\mathrm{p}$ value & 0.770 & 0.373 & 0.064 & 0.379 & 0.035 & 0.470 & 0.597 & 0.952 & 0.975 \\
\hline \multirow[t]{2}{*}{ Relapse } & $\begin{array}{l}\text { Spearman's } \\
\text { rho }\end{array}$ & -0.07 & -0.08 & -0.13 & 0.06 & -0.08 & -0.11 & 0.17 & 0.06 & -0.15 \\
\hline & $\mathrm{p}$ value & 0.561 & 0.533 & 0.278 & 0.627 & 0.524 & 0.376 & 0.158 & 0.625 & 0.227 \\
\hline
\end{tabular}

\section{Discussion}

This is the first description of hematological laboratory findings, signs and symptoms at presentation, immunophenotype, cytogenetics, and outcomes of induction chemotherapy for patients with pediatric ALL who received induction chemotherapy at the main referral hospital for pediatric ALL patients in Palestine. The study also established associations between hematological laboratory findings, sociodemographic, and clinical variables of the patients.

The median age at diagnosis in this study was 6.0 with an IQR of 3.5 years. This was comparable to what was reported in a previous large study on Middle Eastern Arab populations [7]. Findings of this study were also consistent with those reported among Saudi Arabians [30], Jordanians [31], and Brazilians [32]. In this study, patients with pediatric ALL were predominantly male in gender (60.9\%). Findings of this study were consistent with those reported in a previous 
larger study in the Middle East [7] and other regional studies in Saudi Arabia [30], Oman [33], and Pakistan [34]. Findings of other studies reported in Brazil were different with regard to the prevalence of pediatric ALL among male and female patients [32, 35].

At presentation, the median hemoglobin concentration was 9.0 with an IQR of $2.7 \mathrm{~g} / \mathrm{dL}$. Hemoglobin levels reported in this study were comparable to those reported in a previous larger study in the Middle East [7] and other regional studies in Jordan [31] and Brazil [32]. Hemoglobin levels differed significantly between children older and younger than 5 years and those who had T-ALL or B-ALL. Findings of this study were consistent with those reported in previous studies $[10,25]$. The median platelet count was 80,000 with an IQR of 157000 platelets/mm3. In a previous larger study in the Middle East, the platelet count was 36,600 platelets/mm3 [7]. In this study, patients who had splenomegaly and those who had bleeding symptoms had significantly lower platelet count than patients without splenomegaly and bleeding symptoms. Platelet counts after induction chemotherapy could be useful in treatment stratification of patients with pediatric ALL $[16,17]$. Platelet counts could also be used in predicting prognosis and response to chemotherapy [16, 20]. The median initial WBCs count was 7,100 with an IQR of 20,600 cells/mm3. The median initial WBCs counts were significantly different between patients who had T-ALL and BALL. Similarly, the absolute neutrophils counts were also significantly different between patients who had T-ALL and B-ALL. Our findings were consistent with the reported complete blood count and clinical findings of patients with pediatric ALL [10].

Pediatric ALL has many clinical manifestations and patients usually symptomatic at presentation. Usually, symptoms result from dysfunction of the different blood cells. In this study, pallor (72.5\%), fever (53.6\%), bone pain (43.5\%), abdominal pain (31.9\%) and bleeding symptoms (21.7\%) were the main manifestations at presentation. Our findings showed that pollar was significantly associated with T-ALL. Presence of hepatomegaly was significantly associated with splenomegaly. Manifestations reported in this study were consistent with those reported in larger studies in the Middle East where fever (75.5\%), bone pain (39.6\%), and bleeding symptoms (30.8\%) were the most frequent manifestations of pediatric ALL [7]. In Saudi Arabia, patients presented with fever (70\%), bleeding symptoms (18\%), and bone pain (10\%) [30]. In this study, splenomegaly was reported in $49.3 \%$ of the patients. Al-Mulla et al reported that $60.8 \%$ of patients with pediatric ALL had splenomegaly [7]. Among Saudi Arabians with pediatric ALL, $42 \%$ of the patients had splenomegaly [30]. In Brazil, Lustosa de Sousa et al reported that $57.8 \%$ of the patients with pediatric ALL had splenomegaly [32]. Hepatomegaly was present in $49.3 \%$ of the patients with pediatric ALL included in this study. Findings of this study were consistent with those reported in the region among Arab populations in the Middle East and Saudi Arabia as well as those reported among Brazilians [7, 30, 32].

Consistent with international and regional studies, $79.7 \%$ of the patients had B-ALL and $20.3 \%$ of the patients had T-ALL. Findings of this study mirrored those reported in international studies as well as those reported in the Middle East and the region. B-ALL was prevalent in $85 \%$ of Middle Eastern patients with ALL [7], $82 \%$ of Saudi Arabian patients [30], and $89.5 \%$ of Brazilian patients [32].

Findings of this study reported that the vast majority of the patients (95.7\%) had CNS status 1. Our findings were consistent with those reported among Middle Eastern, Saudi Arabian, Moroccan, and Brazilian patients with pediatric ALL [7, 30, 32, 36]. In this study, $1.4 \%$ and $2.9 \%$ of the patients had CNS status 2 and CNS status 2, respectively. Again, these results were comparable with those reported among Middle Eastern, Saudi Arabian, Moroccan, and Brazilian patients with pediatric ALL $[7,30,32,36]$.

Although cytogenetic studies were not conducted for all patients, findings of this study were consistent with those reported for the hyperdiploidy, $t(12,21)$, $t(1,19)$, and $t(9,22)$ translocations among patients with pediatric ALL. For example, in a study conducted in King Hussein Center in Jordan reported that about $12 \%$ of the patients with pediatric ALL were positive for translocation $(12,21), 1.7 \%$ were positive for translocation $(1,19)$, and $7.4 \%$ were positive for translocation $(9,22)$ [31]. Among Middle Easter patients with pediatric ALL, 5.1\% had $(9,22)$ translocation $[7]$. In Chinese patients, $12.5 \%$ had $(9,22), 8.3 \%$ had $(1,19)$, and $41.6 \%$ did not have genetic abnormalities [37]. In contrast, another study conducted in Iran reported that hyperdiploidy was the most prevalent cytogenetic abnormality (32\%) among patients with pediatric ALL [38].

After induction chemotherapy, the vast majority (98.5\%) of the patients included in this study had complete remission. In a larger Middle Eastern study, remission rate was as high as $96.6 \%$ [7]. In Jordan, the remission rate was 7\% [31]. In this study, $7.2 \%$ of the patients who showed complete remission developed relapse. Relapse rates after complete remission showed variability in previously reported studies in Jordan (9\%) and Pakistan (20\%) [31, 34].

\section{Strengths and limitations}

Findings of this study might be interpreted after carefully considering the following strengths and limitations. First, this investigation is the first to describe clinical characteristics and outcomes of patients with pediatric ALL in Palestine. Palestinian patients were not included in previous large studies in the Middle East [7]. Second, correlations between sociodemographic and clinical characteristics of the patients were also included in the descriptive approach followed in this study. Third, this study was based on data collected from the medical record of the patients. Although a data collection form was specifically designed for this study and field researchers had access to the records as many times as they needed, the data collected could be biased by incorrectly entered information in the medical records. Fourth, this was a single-center study. Although An-Najah National Hospital has emerged as the main referral center for patients with leukemia, including those with pediatric ALL in the West Bank and Gaza Strip, inclusion of other centers could have permitted complete description of patients with pediatric ALL in Palestine. Fifth, the sample size included in this study was relatively small. This could be attributed to the fact that care for patients with cancer is based on fragmentation and patients often receive healthcare outside Palestine. Finally, determining more accurate relapse needs longer time as patients need to be followed for 2-3 years after complete remission to decide if a patient developed relapse or not.

\section{Conclusion}

Overall, this study provides insights into the clinical characteristics and outcomes of induction chemotherapy in Palestinian patients with pediatric ALL. The characteristics of ALL among Palestinians were comparable to their peers in the region. The outcomes of induction chemotherapy were also comparable to other published data for ALL patients. More studies are still needed to determine the cytogenetics and relapse rates after induction of chemotherapy. 


\section{Abbreviations}

ALL: Acute lymphoblastic leukemia

B-ALL: B-cell precursor immunophenotype-acute lymphoblastic leukemia

CNS: Central nervous system

IQR: Interquartile range

IRB: Institutional Review Board

MECCA: Middle East Childhood Cancer Alliance

T-ALL: T-cell precursor immunophenotype-acute lymphoblastic leukemia

WBC: White blood cell

WHO: World Health Organization

\section{Declarations}

\section{Availability of data and materials}

The datasets generated and/or analyzed during the current study are available from the corresponding author on reasonable request for privacy reasons.

\section{Supplementary information}

The data collection for is shown in Additional file 1.

Additional Table S1. The data collection form

\section{Acknowledgements}

Authors would like to thank An-Najah National Hospital and An-Najah National University for permitting and facilitating this study.

\section{Authors' contributions}

RS and SM concepted and designed the study. SM, YO, RH, and MA collected the data. RS, SM, YO, RH, and MA contributed to data analysis. RS interpreted the data. RS, SM, YO, RH, and MA drafted the manuscript. RS critically revised the manuscript. All authors approved the final manuscript.

\section{Funding}

None.

\section{Ethics approval and consent to participate}

The protocol and ethics of this study were approved by the Institutional Review Board (IRB) of An-Najah National University under the archived number (IRB20-2017). Data and information leading to the identity of the patient were not collected into the data collection form. The data were coded during the data analysis.

\section{Consent for publication}

Not applicable.

\section{Competing interests}

The author declare that they have no competing interests.

\section{References}

1. Kharroubi AT, Seir RYA: Cancer care in Palestine. In: Cancer care in countries and societies in transition. edn.: Springer; 2016 : 77-97.

2. Halahleh K, Gale RP: Cancer care in the Palestinian territories. The Lancet Oncology 2018, 19(7):e359-e364.

3. Smith MA, Seibel NL, Altekruse SF, Ries LA, Melbert DL, O'Leary M, Smith FO, Reaman GH: Outcomes for children and adolescents with cancer: challenges for the twenty-first century. Journal of clinical oncology : official journal of the American Society of Clinical Oncology 2010, 28(15):2625-2634.

4. Siegel R, Naishadham D, Jemal A: Cancer statistics, 2012. CA: a cancer journal for clinicians 2012, 62(1):10-29.

5. Inaba H, Greaves M, Mullighan CG: Acute lymphoblastic leukaemia. Lancet 2013, 381(9881):1943-1955.

6. Wintrobe MM: Wintrobe's clinical hematology, vol. 1: Lippincott Williams \& Wilkins; 2009. 
7. Al-Mulla NA, Chandra P, Khattab M, Madanat F, Vossough P, Torfa E, Al-Lamki Z, Zain G, Muwakkit S, Mahmoud S et al: Childhood acute lymphoblastic leukemia in the Middle East and neighboring countries: a prospective multi-institutional international collaborative study (CALLME1) by the Middle East Childhood Cancer Alliance (MECCA). Pediatric blood \& cancer 2014, 61(8):1403-1410.

8. Hunger SP, Mullighan CG: Acute Lymphoblastic Leukemia in Children. The New England journal of medicine 2015, 373(16):1541-1552.

9. Zhang H, Wang H, Qian X, Gao S, Xia J, Liu J, Cheng Y, Man J, Zhai X: Genetic mutational analysis of pediatric acute lymphoblastic leukemia from a single center in China using exon sequencing. 2020, 20(1):211.

10. Jaime-Pérez JC, García-Arellano G, Herrera-Garza JL, Marfil-Rivera LJ, Gómez-Almaguer D: Revisiting the complete blood count and clinical findings at diagnosis of childhood acute lymphoblastic leukemia: 10-year experience at a single center. Hematol Transfus Cell Ther 2019, 41(1):57-61.

11. Vardiman JW, Thiele J, Arber DA, Brunning RD, Borowitz MJ, Porwit A, Harris NL, Le Beau MM, Hellström-Lindberg E, Tefferi A et al: The 2008 revision of the World Health Organization (WHO) classification of myeloid neoplasms and acute leukemia: rationale and important changes. Blood 2009, 114(5):937951.

12. Raetz EA, Teachey DT: T-cell acute lymphoblastic leukemia. Hematology Am Soc Hematol Educ Program 2016, 2016(1):580-588.

13. Arber DA, Orazi A, Hasserjian R, Thiele J, Borowitz MJ, Le Beau MM, Bloomfield CD, Cazzola M, Vardiman JW: The 2016 revision to the World Health Organization classification of myeloid neoplasms and acute leukemia. Blood 2016, 127(20):2391-2405.

14. Hakeem A, Shiekh AA, Bhat GM, Lone AR: Prognostification of ALL by Cytogenetics. Indian J Hematol Blood Transfus 2015, 31(3):322-331.

15. Cordas Dos Santos DM, Eilers J, Sosa Vizcaino A, Orlova E, Zimmermann M, Stanulla M, Schrappe M, Börner K, Grimm D, Muckenthaler MU et al: MAP3K7 is recurrently deleted in pediatric T-lymphoblastic leukemia and affects cell proliferation independently of NF-KB. 2018, $18(1): 663$.

16. Zeidler L, Zimmermann M, Möricke A, Meissner B, Bartels D, Tschan C, Schrauder A, Cario G, Goudeva L, Jäger S et al: Low platelet counts after induction therapy for childhood acute lymphoblastic leukemia are strongly associated with poor early response to treatment as measured by minimal residual disease and are prognostic for treatment outcome. Haematologica 2012, 97(3):402-409.

17. Grunnan JD, Rosthøj S: Time course of peripheral blood count recovery during induction chemotherapy for childhood acute lymphoblastic leukemia. Hematology (Amsterdam, Netherlands) 2019, 24(1):467-472.

18. Chua LL, Rajasuriar R, Lim YAL, Woo YL, Loke P, Ariffin H: Temporal changes in gut microbiota profile in children with acute lymphoblastic leukemia prior to commencement-, during-, and post-cessation of chemotherapy. 2020, 20(1):151.

19. Seiter K, Sarkodee-Adoo C, Talavera F, Sacher R, Besa E: Acute lymphoblastic leukemia. Sarkodee-Adoo C, Talavera F, Sacher RA and Besa EC: Medscape Reference WebMD Accessed 2014, 17.

20. Yan A, Erdman L, Sung L, Bernstein S: Teetering on a liver's edge: a case report highlighting clinical decision-making in thrombocytopenia. $B M C$ cancer 2019, 19(1):1058.

21. Oskarsson T, Söderhäll S, Arvidson J, Forestier E, Montgomery S, Bottai M, Lausen B, Carlsen N, Hellebostad M, Lähteenmäki P et al: Relapsed childhood acute lymphoblastic leukemia in the Nordic countries: prognostic factors, treatment and outcome. Haematologica 2016, 101(1):68-76.

22. Zhang X, Wu H, Fan H, Su B, Zhang G, Dong L: Clinical characteristics and prognosis of pediatric patients with B cell acute lymphoblastic leukemia relapse. Oncol Lett 2018, 16(3):2929-2934.

23. Collier JAB, Collier J, Longmore M, Longmore JM, Amarakone K: Oxford handbook of clinical specialties: Oxford University Press; 2013.

24. Gaynon PS, Angiolillo AL, Carroll WL, Nachman JB, Trigg ME, Sather HN, Hunger SP, Devidas M: Long term results of the Children's Cancer Group Studies for childhood acute lymphoblastic leukemia 1983-2002: a Children's Oncology Group report. Leukemia 2010, $24(2): 285$.

25. Teuffel O, Stanulla M, Cario G, Ludwig WD, Rottgers S, Schafer BW, Zimmermann M, Schrappe M, Niggli FK: Anemia and survival in childhood acute lymphoblastic leukemia. Haematologica 2008, 93(11):1652-1657.

26. Rivera-Luna R, Shalkow-Klincovstein J, Velasco-Hidalgo L, Cárdenas-Cardós R, Zapata-Tarrés M, Olaya-Vargas A, Aguilar-Ortiz MR, Altamirano-Alvarez E, Correa-Gonzalez C, Sánchez-Zubieta F et al: Descriptive Epidemiology in Mexican children with cancer under an open national public health insurance program. BMC cancer 2014, 14:790.

27. Bailony MR, Hararah MK, Salhab AR, Ghannam I, Abdeen Z, Ghannam J: Cancer registration and healthcare access in West Bank, Palestine: a GIS analysis of childhood cancer, 1998-2007. International journal of cancer 2011, 129(5):1180-1189.

28. Ayesh BM, Harb WM, Abed AA: Thiopurine methyltransferase genotyping in Palestinian childhood acute lymphoblastic leukemia patients. $B M C$ hematology 2013, 13(1):3.

29. Abuhelwa Z, Al Shaer Q, Taha S, Ayoub K, Amer R: Characteristics of De Novo Acute Myeloid Leukemia Patients in Palestine: Experience of An-Najah National University Hospital. Asian Pacific journal of cancer prevention : APJCP 2017, 18(9):2459-2464.

30. Al Omari A, Hussein T, Albarrak K, Habib A, Sambas A, Sheblaq N, Omair A: Clinical characteristics and outcomes of acute lymphoblastic leukaemia in children treated at a single tertiary hospital in Riyadh, Saudi Arabia. Journal of Health Specialties 2018, 6(1):14-18.

31. Halalsheh H, Abuirmeileh N, Rihani R, Bazzeh F, Zaru L, Madanat F: Outcome of childhood acute lymphoblastic leukemia in Jordan. Pediatric blood \& cancer 2011, 57(3):385-391.

32. Lustosa de Sousa DW, de Almeida Ferreira FV, Cavalcante Félix FH, de Oliveira Lopes MV: Acute lymphoblastic leukemia in children and adolescents: prognostic factors and analysis of survival. Revista Brasileira de Hematologia e Hemoterapia 2015, 37(4):223-229.

33. Knox-Macaulay HH, Brown LC: Descriptive epidemiology of de novo acute leukaemia in the Sultanate of Oman. Leukemia research 2000, 24(7):589-594.

34. Siddiqui EU, Kazi SG, Habib MI, Ahmed Khan KM, Zia N: Pattern of relapse in paediatric acute lymphoblastic leukaemia in a tertiary care unit. JPMA The Journal of the Pakistan Medical Association 2016, 66(8):961-967.

Page $11 / 12$ 
35. Ibagy A, Silva DB, Seiben J, Winneshoffer APFF, Costa TEJB, Dacoregio JS, Costa I, Faraco D: Leucemia linfoblástica aguda em lactentes: 20 anos de experiência. Jornal de Pediatria 2013, 89:64-69.

36. Bachir F, Bennani S, Lahjouji A, Cherkaoui S, Harif Mh, Khattab M, Nassereddine I, Zafad S, El Aouad R: Characterization of Acute Lymphoblastic Leukemia Subtypes in Moroccan Children. International Journal of Pediatrics 2009, 2009:674801.

37. Tien H-F, Wang C-H, Lee F-Y, Liu M-C, Chuang S-M, Chen Y-C, Shen M-C, Lin D-T, Lin K-H, Chuu W-M: Cytogenetic study of acute lymphoblastic leukemia and its correlation with immunophenotype and genotype. Cancer Genetics and Cytogenetics 1992, 59(2):191-198.

38. Safaei A, Shahryari J, Farzaneh MR, Tabibi N, Hosseini M: Cytogenetic Findings of Patients with Acute Lymphoblastic Leukemia in Fars Province. Iranian Journal of Medical Sciences 2013, 38(4):301-307.

\section{Supplementary Files}

This is a list of supplementary files associated with this preprint. Click to download.

- Additionalfile1.xlsx 